\title{
The Impact of Setting Accommodation on Large-scale Assessment for English Language Learners with and without Learning Disabilities: Balanced vs. Unbalanced Data in Latent Class Analyses
}

\author{
Pei-Ying Lin \\ Dept. of Educational Psychology \& Special Education, University of Saskatchewan \\ 28 Campus Drive, Saskatoon, Saskatchewan S7N0X1, Canada \\ E-mail: pei-ying.lin@usask.ca \\ Yu-Cheng Lin \\ Dept. of Psychology, University of Texas at El Paso \\ 500 W. University Ave., El Paso, Texas, 79902, United States \\ E-mail: ylin2@miners.utep.edu
}

Received: March 11, 2013 Accepted: April 2, 2013 Published: May 1, 2013

doi:10.5296/jse.v3i2.3371ＵRL: http://dx.doi.org/10.5296/jse.v3i2.3371

\begin{abstract}
This exploratory study examined the effect of setting accommodation on Grade 6 students' number sense and numeration skill in relation to whether they speak a language other than English at home, have a learning disability, and received setting accommodation for a large-scale math assessment. A set of latent class analyses was conducted to investigate students' response patterns and latent class memberships in both balanced and unbalanced data; three- and two-way ANOVA were also performed to examine the effect. The results suggest that a 4-class model with a covariate and indirect effects have better model fit to the balanced and unbalanced data. Percentage correct and missing response rate in two datasets were also compared and discussed. The results indicate that number sense and numeration skill of accommodated Grade 6 students with LD was comparable to their non-accommodated peers with LD when their response patterns were taken into account. For non-disabled groups, non-accommodated Grade 6 students outperformed their accommodated
\end{abstract}




\section{Macrothink}

Journal of Studies in Education

ISSN 2162-6952 2013, Vol. 3, No. 2

counterparts. The language spoken at home by students was not a significant indicator of the effect. The implication for data design of latent class analysis and parametric statistics for large-scale data was also discussed in this paper.

Keywords: English language learners, Learning disabilities, Latent class analysis, Number sense and numeration skill, Setting accommodation 


\section{Introduction}

It is well documented that in North America there is a growing population of students attending English-language schools whose first language is not English (e.g., Aud et al., 2010; OELA, 2008; Ontario Ministry of Education, 2009; Statistics Canada, 2006). Due to this large population, educators, parents and policy makers are facing special challenges for helping English language learners (ELL) -students with and without disabilities- fulfill their potential and succeed (Lovett et al., 2008). According to Zehler et al. (2003), ELL students with disabilities constituted 9\% of all ELL students in kindergarten to Grade 12 in 2001-2002 in the United States. Moreover, 8.2\% of all students with disabilities are ELL students. Specific learning disabilities are the most salient disability category among ELL students (5.16\% of all ELL students). The challenges for ELL students with disabilities are even more profound than the challenges for other students. In particular, research has shown that ELL students with disabilities are often low achievers (e.g., Liu, Barrera, Thurlow, Guven, \& Shyyan, 2005; Liu, Thurlow, Barrera, Guven, \& Shyyan, 2005).

In order to measure learning outcomes of ELL students with and without disabilities, they have been included in large-scale assessments. In these assessments, some ELL students with disabilities are provided with accommodations (e.g., large print, extended time, computers), consistent with the student's Individual Education Plan (IEP) and regular classroom practices (Albus \& Thurlow, 2008; EQAO, 2012). According to the interaction hypothesis, appropriate accommodations will remove unnecessary barriers and help students to demonstrate their actual skills, abilities and knowledge on the assessments (e.g., National Research Council, 2004; Sireci, Scarpati, \& Li, 2005). Appropriate accommodations can help maintain the construct validity of assessments. The testing adaptations are important not only for students with disabilities, but also for ELL students who have also been diagnosed as having special needs. However, accommodations for ELL students with special needs are rarely researched in the current literature, especially for a frequently used accommodation and a fundamental numerical skill (number sense). The present study investigated this important issue in order to fill this critical gap in the current literature. In addition, this study further examined a critical measurement issue related to unbalanced sample sizes of accommodated and comparison groups. It has been reported that there has not been a large enough sample size of students with LD in accommodation-related studies (Middleton \& Laitusis, 2007). The present study scrutinized the complexity of student characteristics (LD and ELL), examinees' number sense skill, and sample size of groups of interest in relation to whether or not examinees received setting accommodation for math.

\subsection{Accommodations for English Language Learners}

Previous studies have expressed concerns about the impact of such accommodations for ELL students in large-scale assessments; that is, some accommodations appear to be are more appropriate than others for ELL students (e.g., Abedi \& Gándara, 2006; Abedi, Hofstetter, \& Lord, 2004; Abedi, Lord, Hofstetter, \& Baker, 2000; Kopriva, Emick, Hipolito-Delgado, \& Cameron, 2007) although the studies yielded inconclusive findings. In addition to accommodations, it is also important to take various student characteristics into account while 
examining school achievement of ELL students with and without disabilities (e.g., Abedi et al., 2000; Abedi et al., 2004).

Many large-scale assessments provide ELL student with setting accommodation. For example, the only special provision for these students participating in Ontario's provincial assessments is setting accommodation (EQAO, 2012). However, the impact of setting accommodation is rarely examined in current literature. As such, it is important to examine the effect of this frequently used accommodation for students who speak a language other than English at home.

\subsection{Setting Accommodation}

Setting accommodation has been well known to be one of the most commonly used accommodations (e.g., Cawthon, 2010; Thurlow, Lazarus, Thompson, \& Morse, 2005). This accommodation may accompany other accommodations that require a quiet environment (such as dictation, read aloud, tape recording of responses) or/and individual administration. Although many studies have examined the effects of multiple test accommodations including alternative setting (e.g., Bolt \& Ysseldyke, 2006; Lewandowski et al., 2008; Thurlow, Elliott, \& Ysseldyke, 2003), research rarely studies the separate effect of setting accommodation. To address this, the present study combined an examination of the setting accommodation for this population with latent class analysis.

\subsection{Number Sense}

Number sense, an ability to recognize number patterns, conduct numerical operations and calculate the relation of number to quantity, is critical for students to understand in early childhood (Gersten \& Chard, 1999; Rotem \& Henik, 2013). A number of studies reported indicate that young children with math disabilities are substantially weaker in many aspects of math, such as magnitude comparison, complicated counting strategies, and digit naming speed (Geary, 1990; Gersten, Jordan, \& Flojo, 2005; Goldman \& Pellegrino, 1987). Moreover, they are more likely to use immature and insufficient strategies such as finger counting when they attempt to solve simple arithmetic problems (e.g., Butterworth, 1999; Jordan, Hanich, \& Kaplan, 2003a, 2003b; Ostad, 1999).

For ELLs, previous studies show that linguistic modified math items may affect ELLs' assessment performance (e.g., Abedi \& Lord, 2001; Abedi, Lord, Hofstetter, \& Baker, 2000; Alt, Arizmendi, Beal, Hurtado, 2013). More specifically, Rodriguez, Parmar, and Signer (2001) reported that a group of students from culturally and linguistically diverse backgrounds (Spanish native speakers) with LD and non-ELL students with LD only have more limited number line concepts (such as relative position of numbers and connecting number to quantity) than students without disabilities. The interactive effect of setting accommodation, LD, ELL, and this important numerical concept is still unknown, and that is why the current study focuses on these factors.

\subsection{Balanced versus Unbalanced Data}

Because the LD group of interest is a subgroup of the student population, it is unclear whether the statistical analyses should be conducted by using the whole population or simply the LD group. This question is further complicated by another question regarding the unbalanced 
sample sizes between LD and non-disabled groups. Previous studies using latent class analysis (LCA) employed data with unbalanced sample sizes (e.g., Hickendorff, Heiser, Van Putten, \& Verhelst, 2009; Lesaux \& Kieffer, 2010; Penuel, Boscardin, Masyn, \& Crawford, 2007). However, it is not unusual for the sample size of the studied groups to be reduced through random sampling procedures at the stage of data collection, preparation and management (e.g., Cook, Eignor, Sawaki, Steinberg, \& Cline, 2010; Middleton \& Laitusis, 2007). For a large-scale study by Rohde et al. (2001), 64 schools were randomly selected from 246 state schools where the analyzed sample of approximately 1,000 students was tested. The effect of unbalanced sample sizes in statistical analyses is unclear, and, therefore, the statistical models in the present study were conducted for both unbalanced and balanced data and the results were further compared for both datasets.

\subsection{Research Questions}

This exploratory study, as part of a larger project, is designed to investigate the impact of setting accommodation on ELL students' number sense skill by answering the following questions: (1) what are response patterns of students with different characteristics in balanced and unbalanced data? and (2) does setting accommodation significantly affect the number sense skill of students with different characteristics in balanced data compared with test results derived from unbalanced data? In particular, the effect was examined in relation to three major student characteristics: setting accommodation or standard testing, ELL or native English speakers, LD or non-disabled.

\section{Method}

\subsection{Participants}

This study used latent class analyses (LCA) to examine data from Ontario's provincial standardized testing program developed and administered by the Education Quality and Accountability Office (EQAO). The data from students who took the Junior (Grade 6) Assessment of Reading, Writing and Mathematics in 2005-2006 were analyzed $(N=133,059)$.

In preparation for data analyses, some students were excluded from the study if they: (1) took the French version, (2) were enrolled in a French Immersion program, (3) were exempted in one of more subject areas, or (4) were missing any necessary information (specifically, students who were missing information about IEP or IPRC, setting accommodation information for math, or home language information from the student questionnaire, or had no item response data), leaving a total of 131,620 students.

\subsection{Unbalanced Data with Setting Accommodation}

To analyze the effect of the setting accommodation alone, an unbalanced version of the dataset was created, from which students who received accommodations other than or in addition to the setting accommodation were excluded, leaving only students who received no accommodation or setting accommodation alone. This dataset was comprised of 114,034 students for math (Table 1). This dataset includes a large cohort of students who speak languages other than English $(N=50,778,45 \%)$. Table 1 shows the numbers of students in this 
dataset by disability status, use of the setting accommodation, and English language learning status.

Given the complexity of characteristics and the diverse backgrounds of ELLs, ELL students in this study refers to examinees who speak a language other than English at home. Because accurate ELL status information is not available from local schools and so it is not possible to determine which students receive language supports in school, language status of ELLs in this study was defined by the indicator of home language from the EQAO's student questionnaire. Many research studies have used the language variable, home language, to identify students as ELL (e.g., Abedi, Lord, \& Plummer, 1997; Abedi \& Lord, 2001; Chiappe \& Siegel, 2006). Considering all these issues, in the present study, if students reported that they never or sometimes speak English at home (meaning that they speak another language at home instead of or in addition to English), they were classified in this study as ELL students $(N=50,778)$ (Table 1); this is a broader definition of ELL than is typically used in education. Of this study population, $1.43 \%$ of ELL students were identified as having LD. The comparison group was the students who always speak English at home $(N=63,256 ; 55 \%)$ (Table 1). Of the monolingual English-speaking students, 2.07\% were identified as having LD. The percentages of students with LD in both language groups are small because students using accommodations other than or in addition to the setting accommodation were excluded from the analyses.

Students with LD in this study were the students who had been formally identified by the Identification, Placement, and Review Committee (IPRC) in Ontario (Ontario Ministry of Education, 2009); students identified with dual or multiple exceptionalities were not included in the analyses.

\subsection{Balanced Data with Setting Accommodation}

Because there are larger numbers of both English-speaking only and ELL students without learning disabilities than with learning disabilities, to create a balanced dataset, a number of students without disability and accommodation were randomly selected from the unbalanced dataset with only setting accommodation to avoid the possible significant impact due to having a large sample size (ELL: $n=843$, non-ELL: $n=1000$ ) (Table 1). The proportions of ELL and English-speaking only students were selected to resemble the original proportions in the population (45\%, 55\%, respectively).

It should be noted that the numbers of students with LD and the numbers who received the setting accommodation are the same for both balanced and unbalanced data in the present study (Table 1). However, the unbalanced dataset was much larger than the random sampling balanced dataset, and thus students with LD are 45 percent of the balanced sample, but only 1.8 percent of the unbalanced data.

Table 1. Frequencies of ELL and English-Speaking Only Students with and without LD and Setting Accommodation

\section{Unbalanced Data}

\begin{tabular}{|c|c|c|}
\hline Disa & Setting & $\begin{array}{l}\text { Native English } \\
\text { Speakers }\end{array}$ \\
\hline Status & Accommodation & ELL Students \\
\hline
\end{tabular}




\begin{tabular}{|c|c|c|c|c|c|c|c|}
\hline \multirow[t]{3}{*}{ LD } & None & 578 & $79.70 \%$ & 1079 & $82.50 \%$ & 1657 & $81.50 \%$ \\
\hline & Setting Only & 147 & $20.30 \%$ & 229 & $17.50 \%$ & 376 & $18.50 \%$ \\
\hline & Subtotal & 725 & $100.00 \%$ & 1308 & $100.00 \%$ & 2033 & $100.00 \%$ \\
\hline \multirow{4}{*}{$\begin{array}{c}\text { Non- } \\
\text { disabled }\end{array}$} & None & 49706 & $99.30 \%$ & 61661 & $99.50 \%$ & 111367 & $99.40 \%$ \\
\hline & Setting Only & 347 & $0.70 \%$ & 287 & $0.50 \%$ & 634 & $0.60 \%$ \\
\hline & Subtotal & 50053 & $100.00 \%$ & 61948 & $100.00 \%$ & 112001 & $100.00 \%$ \\
\hline & Total & 50778 & & 63256 & & 114034 & \\
\hline \multicolumn{8}{|c|}{ Balanced Data } \\
\hline Disability & Setting & \multicolumn{6}{|c|}{ Native English } \\
\hline Status & Accommodation & \multicolumn{2}{|c|}{ ELL Students } & \multicolumn{2}{|c|}{ Speakers } & \multicolumn{2}{|c|}{ Total } \\
\hline \multirow[t]{3}{*}{ LD } & None & 578 & $79.70 \%$ & 1079 & $82.50 \%$ & 1657 & $81.50 \%$ \\
\hline & Setting Only & 147 & $20.30 \%$ & 229 & $17.50 \%$ & 376 & $18.50 \%$ \\
\hline & Subtotal & 725 & $100.00 \%$ & 1308 & $100.00 \%$ & 2033 & $100.00 \%$ \\
\hline \multirow{4}{*}{$\begin{array}{c}\text { Non- } \\
\text { disabled }\end{array}$} & None & 843 & $70.80 \%$ & 1000 & $77.70 \%$ & 1843 & $74.40 \%$ \\
\hline & Setting Only & 347 & $29.20 \%$ & 287 & $22.30 \%$ & 634 & $25.60 \%$ \\
\hline & Subtotal & 1190 & $100.00 \%$ & 1287 & $100.00 \%$ & 2477 & $100.00 \%$ \\
\hline & Total & 1915 & & 2595 & & 4510 & \\
\hline
\end{tabular}

\section{Data Analyses}

The present study used Mplus 5 (Muthén \& Muthén, 2007) to conduct latent class analyses (McCutcheon, 1987, 2002) to determine whether examinees with different characteristics show distinct response patterns on a set of number sense and numeration items. Six math multiple-choice items of number sense and numeration were selected as outcome variables in the mixture modeling. More complex models were also estimated by allowing a covariate to have direct and indirect effects on the outcome variables. The proportion of items correct of all EQAO's 28 math binary items was calculated and included in the 2, 3, and 4 latent class models as a covariate. The latent class models with a covariate were then tested separately for direct and indirect effects to address question 1 . The latent class models were built separately on unbalanced and balanced data.

To address question 2, three-way and two-way analysis of variance (ANOVA) were conducted to examine the effect of setting accommodation on students' number sense and numeration skills. These analyses were performed separately using unbalanced and balanced data.

\section{Results}

\subsection{Question 1-Latent Class Models \& Memberships}

Latent class analyses were also performed using the balanced data. For these data, the 2-, 3-, and 4-class models without the covariate show a poor model fit (Appendix 1). According to the fit indices, the model fit of the 2-, 3-, and 4-class models with direct effects is considered as 
good as the 4-class model with indirect effect and the covariate. However, further examination of the response patterns show that the former models rely on the accuracy of a single item to assign class membership. As a result, the subsequent analyses on balanced data were based on the 4-class model with indirect effects. This model has relatively high entropy (.797), relatively small value of -2 loglikelihood (29772.116) and relatively small Bayesian information criterion $(\mathrm{BIC}=30024.418)$. Although the two compared sets of data were analyzed using the same model, there are similarities and differences regarding the results which are discussed in the following sessions.

Appendix 2 shows the parameters and fit indices for the 2-, 3-, and 4-class models with the covariate and indirect effects as well as the models without the covariate. The results showed that the three models with the covariate fit the data better than the models without the covariate. Although the 2- and 3-class models with direct effects seems to have the high entropy (.852, .839, respectively), the class assignments were exactly related to the number of items answered correctly, so that they are not an ideal model. In similar fashion, the 4-class model with a covariate and direct effects was also excluded. The 4-class model with indirect effects has a relatively high entropy (.798), a relatively small value of -2 loglikelihood (871249.658) and relatively small Bayesian information criterion (BIC $=871603.615)$; it also has better interpretability. Thus, this 4-class model was chosen as the best model for unbalanced data.

Appendices 3 and 4 show the numbers of the students of interest grouped in the four latent classes in the two compared datasets. Note that different numbers of students were missed in the latent class analyses in balanced $(n=91,2 \%)$ and unbalanced data $(n=134,0.1 \%)$. Given that the original numbers of students of interest were the same for the latent class analyses based on two datasets, the total numbers of students in latent classes has been changed.

Appendix 5 and Figure 1 show the percentage correct of each item for students in the four latent classes in both datasets. Although the percentage correct varies from item to item for students in the four latent classes in the balanced data, the item difficulty for students in different latent classes remains more consistent. Class 1 in the unbalanced data has a more distinct pattern in terms of item difficulty for a few items (Items 1 and 2). Take Item 1 as an example: the percentage correct is $100 \%, 50 \%, 48 \%$ and $58 \%$ for Classes 1 to 4 , respectively. This item was much easier for students in Class 1 than those in other classes.

The distributions of class memberships are similar for students with and without disabilities using setting accommodation in both compared data sets regardless of their ELL status. They are more likely to be in classes with a lower percentage correct than their counterparts without disabilities and setting accommodation. On the other hand, ELL and native English-speaking students without disability and setting accommodation are more likely to be assigned to the classes with a higher percentage correct in both datasets. This pattern is more obvious in the unbalanced data since approximately one-third of students without disabilities and setting accommodation are in Class 1 which has the highest percentage correct (average 83.98\%).

The percentage correct of students with LD is lower than their non-disabled peers for all six items in the balanced data (LD: $25 \%$ to $49 \%$; non-LD: 35\% to 61\%)(Appendix 6). Students with LD also have a slightly higher missing response rate than their counterparts without disabilities (LD: $0 \%$ to $2.1 \%$; non-LD: $0 \%$ to $1.6 \%$ ). In contrast, the unbalanced data was found 
to have a slightly higher missing response rate for students with and without disabilities (LD: 0\% to 3.1\%; non-LD: $0 \%$ to $1.9 \%$ ) than those in balanced data (Appendix 7).

The percentage correct of students with different characteristics in both datasets, in general, is equivalent; however, non-disabled English-speaking only students in the balanced data have a significantly higher percentage correct (100\% across all four classes) than those in the unbalanced data (average of $61.70 \%$ ) of the first item. The discrepancy may result from the random sampling procedure for the balanced data.

Interestingly, native English speaking students (that is, those who speak only English at home) and use a setting accommodation are more likely to miss math items than those taking the test with standard administration (Balanced data: LD/setting $0 \%$ to $1.4 \%$ vs. LD/standard $0 \%$ to $0.9 \%$; non-LD/setting $0 \%$ to $0.4 \%$ vs. non-LD/standard $0 \%$ to $0.1 \%$ )(Unbalanced: $\mathrm{LD} /$ setting $0.9 \%$ to $1.8 \%$ vs. LD/standard $0.1 \%$ to $2.3 \%$; non- $\mathrm{LD} /$ setting $0.3 \%$ to $1.0 \%$ vs. non-LD/standard $0.2 \%$ to $0.7 \%$ ) (Appendices 6 and 7).

Similarly, ELL students have a slightly higher missing rate if they received a setting accommodation than those tested using standard testing procedures (Balanced data: LD/setting $0 \%$ to $2.8 \%$ vs. $\mathrm{LD} /$ standard $0 \%$ to $1.6 \%$; non-LD/setting $0 \%$ to $0.4 \%$ vs. non-LD/standard $0 \%$ to $0.1 \%$ )(Unbalanced: $\mathrm{LD} /$ setting $0 \%$ to $2.8 \%$ vs. $\mathrm{LD} /$ standard $0 \%$ to $1.6 \%$; non-LD/setting $0 \%$ to $1.7 \%$ vs. non-LD/standard $0.2 \%$ to $0.8 \%$ ).

In general, students with different characteristics (with/without ELL and learning disability status, setting accommodation) in the four latent classes have similar patterns in terms of percentage correct of each item with several exceptions such as Items 3, 5 and 6 in the unbalanced data and Items 1 and 2 in the balanced data (Figures 2 to 5). ELL and native English-speaking students without disabilities are the groups that have consistent response patterns in both datasets.

\subsection{Question 2-Effects of Setting Accommodation on Number Sense and Numeration Skill}

In order to scrutinize whether the effects of ELL and LD and setting accommodation on these six math items vary across the latent classes, two-way and three-way ANOVA, with the total number of correct answers on the six items as the dependent variable, were performed separately for the two datasets. For the balanced data, no significant three-way interaction was found for LD, setting accommodation, and latent class for ELL students $\left(\mathrm{F}_{3,1877}=0.675, p\right.$ $=.567)$ and native English speakers $\left(F_{3,2542}=0.610, p=.608\right)$. However, a two-way interaction of LD and setting accommodation was found (ELL: $F_{1,1915}=6.756, p<.01$; English only: $F_{1}$, $\left.{ }_{2542}=16.170, p<.01\right)$. Therefore, a two-way ANOVA was conducted to further examine the interaction effects. It was found that disability status and setting accommodation have significant interaction effects for ELL students $\left(F_{1,1915}=25.418, p<.01, \eta^{2}=.013\right)$ and native English speakers $\left(F_{1,2595}=58.203, p<.01, \eta^{2}=.022\right)$. With the Bonferroni pairwise comparisons, it was found that accommodated non-disabled students have significantly poorer math performances than their peers taking the test in standard testing procedures (ELL: Standard $M=3.54$, Setting $M=2.40, p<.05$; English only: Standard $M=3.38$, Setting $M=$ 2.06, $p<.05)$. No significant difference was found for students with LD using setting accommodation or standard testing procedures. 
Similarly, no significant 3-way interaction was found for ELL and native English speakers in the unbalanced data (ELL: $F_{3,50721}=5.535, p=.203$; English only: $F_{3,63179}=0.093, p=.964$ ). A significant two-way interaction effect of disability status and setting accommodation was found for English-speaking only students $\left(F_{1,63179}=5.696, p<.05\right)$ and ELL students $\left(F_{1,50721}=27.523, p<.01, \eta^{2}=.001\right)$ and native English speakers $\left(F_{1,63279}=56.244, p<.01, \eta^{2}\right.$ $=.001)$. That these very small effect sizes were found to be statistically significant is likely due to the very large sample size. The analyses of Bonferroni pairwise comparisons revealed the same results from the balanced data for ELL and English-speaking only students: Students using the standard testing administration outperformed those students with a setting accommodation in the non-disabled groups (ELL: Standard $M=3.54$, Setting $M=2.41, p$ $<.05$; English only: Standard $M=3.32$, Setting $M=2.06, p<.05$ ). No significant difference in number sense and numeration skills was found for students with LD testing with setting accommodation or standard testing procedures.

\section{Discussion}

The present study is meant to investigate the impact of setting accommodation on the number sense and numeration skill of students with and without LD. The results of latent class analyses and three- and two-way ANOVA were compared for both balanced and unbalanced data. The results have shown that setting accommodation did not significantly affect this particular skill of ELL and English-speaking only students with LD; however, students without disabilities receiving this accommodation perform poorly on these six math items. It is worth noticing that the interaction effects of disability and setting accommodation do not differ across the four latent classes for both ELL and native English speakers. Therefore, the impact of setting accommodation on math performance does not vary from class to class and for students with high or low math performance. The results provide some information regarding the issues of construct validity, test comparability and differential boost (Fuchs \& Fuchs, 1999; National Research Council, 2004; Sireci, Scarpati, \& Li, 2005). On the one hand, the setting accommodation did not improve or decrease students' math scores on six items, and, therefore, this accommodation is less likely to bring construct relevant threats to the math assessment. Thus, students' math performance on these math items is comparable to the groups of students with LD. On the other hand, it is unknown whether there is differential boost for these students given that this accommodation did not substantially improve their math scores. Moreover, the adverse effects of setting accommodation of non-disabled students should be further investigated. The finding implies that non-disabled students' test performances may not be comparable across standard and non-standard testing conditions. However, the results should be interpreted with caution since the analyses were based on the set of six number sense and numeration items.

The aforementioned findings were applicable to both balanced and unbalanced data. The balanced data consists of comparable numbers of students of interest resulting from the random sampling procedures, whereas the unbalanced data contains all students if any necessary information (e.g., IEP/IPRC, home language, scores) was missing and if their language of instruction is English. Although no difference was found in the results of 3-and 2-way ANOVA for both compared datasets, there are similarities and differences between these two datasets 
when we take the detailed information into account. Entropy, which is the index of classification uncertainty, is equivalent for the balanced and unbalanced data $(.797, .798$, respectively). The missing rate of classification of latent classes is slightly higher for the balanced data (2\%) compared to the unbalanced data $(0.1 \%)$. That is, more response patterns were identified and clustered in the unbalanced data. The classification helps achieve one of the primary goals of latent class analyses -- to understand the unobservable latent traits that contribute to the observed response patterns. The unbalanced data are more likely to be used to accurately estimate the item response probability of a set of items of a large cohort of students without disabilities. The accuracy of probability estimation may affect the way similar response patterns were clustered in a latent class as well as change the probability of examinees' class memberships.

In the present study, it was found that the balanced data contains a lower missing response rate (Appendices 6 and 7). The descriptive and parametric statistics resulting from the balanced data may be more precise and might influence the interpretation of the effects of setting accommodation for students of interest. However, the balanced data yield a higher percentage correct of the first math item than in the unbalanced data although the percentage correct of other items is equivalent in both datasets. Finally, the unbalanced design is closer to the normal data collected from the real world.

\section{Conclusion}

These research findings do not to conclude that balanced or unbalanced data pose problems for latent class analyses. Instead, these results of the present study suggest that researchers should consider the possible consequences (e.g., lower percentage correct or higher missing response rates) yielded from the balanced and unbalanced design for different statistical methods. For descriptive and parametric statistics of large-scale data, balanced data is recommended since it is more likely to result in a lower missing response rate. For latent class analysis, unbalanced data is preferred because it can help identify more response patterns and accurately estimate the item response probability of items.

The findings of the current study also suggest that number sense and numeration skill of accommodated Grade 6 students with LD was comparable to their non-accommodated peers with LD when their response patterns were taken into account. Moreover, for non-disabled groups, non-accommodated Grade 6 students outperformed their accommodated counterparts. The results suggest that it is critical for decision makers (e.g., teachers, test administrators) to evaluate the appropriateness of providing such accommodation to students without disabilities. Further, the reasons for using setting accommodation for students without disabilities should be justified and reported on an individual basis.

\section{Acknowledgement}

Special thanks are given to Dr. Ruth Childs, Associated Dean of the Ontario Institute for Studies in Education of the University of Toronto (OISE/UT), as well as the Education Quality and Accountability Office (EQAO). 


\section{References}

Abedi, J., \& Gándara, P. (2006). Performance of English language learners as a subgroup in large-scale assessment: Interaction of research and policy. Educational Measurement: Issues and Practice, 25(4), 36-46. http://dx.doi.org/10.1111/j.1745-3992.2006.00077.x

Abedi, J., Hofstetter, C. H., \& Lord, C. (2004). Assessment accommodations for English language learners: Implications for policy-based empirical research. Review of Educational Research, 74(1), 1-28. http://dx.doi.org/10.3102/00346543074001001

Abedi, J., \& Lord, C. (2001). The language factor in mathematics tests. Applied Measurement in Education, 14, 219-234. http://dx.doi.org/10.1207/S15324818AME1403_2

Abedi, J., Lord, C., Hofstetter, C. \& Baker, E. (2000). Impact of accommodation strategies on English language learners' test performance. Educational Measurement: Issues and Practice, 19(3), 16-26. http://dx.doi.org/10.1111/j.1745-3992.2000.tb00034.x

Abedi, J., Lord, C., \& Plummer, J. (1997). Language background as a variable in NAEP mathematics performance: NAEP TRP Task 3D: Language background study (CSE Tech. Rep. No. 429). Los Angeles: University of California, National Center for Research on Evaluation, Standards, and Student Testing.

Albus, D., \& Thurlow, M. L. (2008). Accommodating students with disabilities on state English language proficiency assessments. Assessment for Effective Intervention, 33(3), 156-166. http://dx.doi.org/10.1177/1534508407313241

Alt, M., Arizmendi, G. D., Beal, C. R., \& Hurtado, J. S. (2013). The effect of test translation on the performance of second grade English learners on the keymath-3. Psychology in the Schools, 50, 27-36. http://dx.doi.org/10.1002/pits.21656

Aud, S., Hussar, W., Planty, M., Snyder, T., Bianco, K., Fox, M., Frohlich, L., Kemp, J., \& Drake, L. (2010a). The Condition of Education 2010 (NCES 2010-028): Indicator 4Racial/ethnic enrollment in public schools. Washington, DC: National Center for Education Statistics, Institute of Education Sciences, U.S. Department of Education. Retrieved from http://nces.ed.gov/pubs2010/2010028_1.pdf

Bolt, S. E. \& Ysseldyke, J. E. (2006). Comparing DIF across math and Reading/ Language arts tests for students receiving a read-aloud accommodation. Applied Measurement in Education, 19, 329-355. http://dx.doi.org/10.1207/s15324818ame1904_6

Butterworth, B. (1999). The mathematical brain. London: Macmillan.

Cawthon, S. W. (2010). Science and evidence of success: Two emerging issues in assessment accommodations for students who are deaf or hard of hearing. Journal of Deaf Studies and Deaf Education, 15, 185-203. http://dx.doi.org/10.1093/deafed/enq002

Chiappe, P., \& Siegel, L. S. (2006). A longitudinal study of reading development of Canadian children from diverse linguistic backgrounds. The Elementary School Journal, 107, 135-152. http://dx.doi.org/10.1086/510652

Cook, L., Eignor, D., Sawaki, Y., Steinberg, J., \& Cline, F. (2010). Using factor analysis to investigate accommodations used by students with disabilities on an English-language arts assessment. Applied Measurement in Education. Special Issue: Testing Students with Disabilities, 23, 187-208. http://dx.doi.org/10.1080/08957341003673831 
Education Quality and Accountability Office (EQAO)(2012). Guide for accommodations, special provisions and exemptions, 2012 [Primary and Junior Division]. Ontario: Education Quality and Accountability Office.

Fuchs, L. S., \& Fuchs, D. (1999). Fair and unfair testing accommodations. School Administrator, 56(10), 24-24. Retrieved from http://search.proquest.com.cyber.usask.ca/docview/219247425?accountid=14739

Geary, D. C. (1990). A componential analysis of an early learning deficit in mathematics. Journal of Experimental Child Psychology, 49, 363-383. http://dx.doi.org/10.1016/0022-0965(90)90065-G

Gersten, R., \& Chard, D. (1999). Number sense: Rethinking arithmetic instruction for students with mathematical disabilities. The Journal of Special Education, 33, 18-28. http://dx.doi.org/10.1177/002246699903300102

Gersten, R., Jordan, N., \& Flojo, J. (2005). Early identification and interventions for students with mathematics difficulties. Journal of Learning Disabilities, 38, 293-304. http://dx.doi.org/10.1177/00222194050380040301

Goldman, S., \& Pellegrino, J. (1987). Information processing and educational microcomputer technology. Journal of Learning Disabilities, 20, 144-154. http://dx.doi.org/10.1177/002221948702000302

Hickendorff, M., Heiser, W., van Putten, C., \& Verhelst, N. (2009). Solution strategies and achievement in Dutch complex arithmetic: Latent variable modeling of change. Springer New York. http://dx.doi.org/10.1007/s11336-008-9074z

Jordan, N. C., Hanich, L. B., \& Kaplan, D. (2003a). A longitudinal study of mathematical competencies in children with specific mathematics difficulties versus children with co-morbid mathematics and reading difficulties. Child Development, 74, 834-850. http://dx.doi.org/10.1111/1467-8624.00571

Jordan, N. C., Hanich, L. B., \& Kaplan, D. (2003b). Arithmetic fact mastery in young children: A longitudinal investigation. Journal of Experimental Child Psychology, 85, 103-119. http://dx.doi.org/10.1016/S0022-0965(03)00032-8

Kopriva, R. J., Emick, J. E., Hipolito-Delgado, C. P., \& Cameron, C. A. (2007). Do proper accommodation assignments make a difference? Examining the impact of improved decision making on scores for English language learners. Educational Measurement: Issues and Practice, 26(3), 11-20. http://dx.doi.org/10.1111/j.1745-3992.2007.00097.x

Lesaux, N., \& Kieffer, M. (2010). Exploring sources of reading comprehension difficulties among language minority learners and their classmates in early adolescence. American Educational Research Journal, 47(3), 596-632. http://dx.doi.org/10.3102/0002831209355469

Lewandowski, L. J., Lovett, B. J., \& Rogers, C. L. (2008). Extended time as a testing accommodation for students with reading disabilities: Does a rising tide lift all ships? Journal of Psychoeducational Assessment, 26(4), 315-324. http://dx.doi.org/10.1177/0734282908315757

Liu, K., Barrera, M., Thurlow, M., Guven, K., \& Shyyan, V. (2005). Graduation exam participation and performance (1999-2000) of English language learners with disabilities 
(ELLs with Disabilities Report 2). Minneapolis, MN: University of Minnesota, National Center on $\quad$ Educational from http://www.cehd.umn.edu/NCEO/onlinepubs/ELLsDisReport2.html

Liu, K., Thurlow, M., Barrera, M., Guven, K., \& Shyyan, V. (2005). Graduation exam participation and performance (2000-2001) of English language learners with disabilities (ELLs with Disabilities Report 3). Minneapolis, MN: University of Minnesota, National $\begin{array}{lllll}\text { Center on } & \text { Educational from }\end{array}$ http://www.cehd.umn.edu/NCEO/onlinepubs/ELLsDisRpt3.pdf

Lovett, M. W., De Palma, M., Frijters, J., Steinbach, K., Temple, M., Benson, N., et al. (2008). Interventions for reading difficulties: A comparison of response to intervention by ELL and EFL struggling readers. Journal of Learning Disabilities, 41, 333-352. http://dx.doi.org/10.1177/0022219408317859

McCutcheon, A. L. (1987). Latent class analysis. Beverly Hills, CA.: Sage Publications.

McCutcheon, A. L. (2002). Basic concepts and procedures in single-and multiple-group latent class analysis. In J. A. Hagenaars \& A. L. McCutcheon (Eds.), Applied latent class analysis (pp. 57-88). Cambridge, UK: Cambridge University Press.

Middleton, K., \& Laitusis, C. C. (2007). Examining test items for differential distractor functioning among students with learning disabilities. Research Report, 07-43, Princeton, NJ: Educational Testing Service. Retrieved from http://www.ets.org/Media/Research/pdf/RR-07-43.pdf

Muthén, L.K. and Muthén, B.O. (2007). Mplus User's Guide (5th ed.). Los Angeles, CA: Muthén \& Muthén.

National Research Council. (2004). Keeping score for all: The effects of inclusion and accommodation policies on large-scale educational assessments. Committee on Participation of English Language Learners and Students with Disabilities in NAEP and Other Large-Scale Assessments. Judith A. Koenig and Lyle F. Bachman, Editors. Board on Testing and Assessment, Center for Education, Division of Behavioral and Social Sciences and Education. Washington, DC: The National Academies Press.

Office of English Language Acquisition, Language Enhancement, and Academic Achievement for Limited English Proficient Students (OELA)(2008). Biennial Report to Congress on the Implementation of the Title III State Formula Grant Program, School Years 2004-06. Washington, DC.

Ontario Ministry of Education (2009). School information finder. Retrieved from http://www.edu.gov.on.ca/eng/sift/

Ostad, S. E. (1999). Developmental progression of subtraction studies: a comparison of mathematically normal and mathematically disabled children. European Journal of Special Needs Education, 14, 21- 36. http://dx.doi.org/10.1080/0885625990140103

Penuel, W. R., Boscardin, C. K., Masyn, K., \& Crawford, V. M. (2007). Teaching with student response systems in elementary and secondary education settings: A survey study. Educational Technology Research and Development, 55(4), 315-346. http://dx.doi.org/10.1007/s11423-006-9023-4 
Rodriguez, D., Parmar, R. S., \& Signer, B. R. (2001). Fourth-grade culturally and linguistically diverse exceptional students' concepts of number line. Exceptional Children, 67, 199-210. Retrieved from http://cyber.usask.ca/login?url=http://search.ebscohost.com/login.aspx?direct=true\&db=pbh \&AN $=4083984 \&$ site $=$ ehost-live

Rohde, L. A., Barbosa, G., Polanczyk, G., Eizirik, M., Rasmussen, E. R., Neuman, R. J., et al. (2001). Factor and latent class analysis of DSM-IV ADHD symptoms in a school sample of brazilian adolescents. Journal of the American Academy of Child \& Adolescent Psychiatry, 40(6), 711-718. http://dx.doi.org/10.1097/00004583-200106000-00017

Rotem, A., \& Henik, A. (2013). The development of product parity sensitivity in children with mathematics learning disability and in typical achievers. Research in Developmental Disabilities, 34, 831-839. http://dx.doi.org/10.1016/j.ridd.2012.11.001

Sireci, S. G., Scarpati, S. E., \& Li, S. (2005). Test accommodations for students with disabilities: An analysis of the interaction hypothesis. Review of Educational Research, 75(4), 457-490. http://dx.doi.org/10.3102/00346543075004457

Statistics Canada. (2006). Immigration and citizenship. Retrieved from http://www12.statcan.ca/census-recensement/2006/rt-td/immcit-eng.cfm

Thurlow, M. L., Elliott, J. L., \& Ysseldyke, J. E. (2003). Testing students with disabilities: Practical strategies for complying with district and state requirements $\left(2^{\text {nd }} \mathrm{ed}\right.$.). Thousand Oaks, CA: Corwin Press.

Thurlow, M. L., Lazarus, S. S., Thompson, S. J., \& Morse, A. B. (2005). State policies on assessment participation and accommodations for students with disabilities. The Journal of Special Education, 38, 232-240. http://dx.doi.org/10.1177/00224669050380040401

Zehler, A., Fleischman, H., Hopstock, P., Stephenson, T., Pendzick, M., \& Sapru, S. (2003). Policy report: Summary of findings related to LEP and SPED-LEP students. Submitted by Development Associates, Inc. to U.S. Department of Education, Office of English Language Acquisition, Language Enhancement, and Academic Achievement of Limited English $\begin{array}{llll}\text { Proficient } & \text { Students. } & \text { Retrieved }\end{array}$ http://www.ncela.gwu.edu/files/rcd/BE021195/policy_report.pdf

\section{Appendices}

Appendix 1. Parameter Estimates and Fit Indices for the 2-, 3-, and 4-class Models: Balanced Data

\begin{tabular}{|c|c|c|c|c|c|c|c|c|c|}
\hline & $\begin{array}{l}\text { 2-Class } \\
\text { Model } \\
\text { with a } \\
\text { Covariate } \\
\text { (Direct } \\
\text { effects) }\end{array}$ & $\begin{array}{l}\text { 2-Class } \\
\text { Model } \\
\text { with a } \\
\text { Covariate } \\
\text { (Indirect } \\
\text { effects) }\end{array}$ & $\begin{array}{l}\text { 2-Class } \\
\text { Model } \\
\text { without a } \\
\text { Covariate }\end{array}$ & $\begin{array}{l}\text { 3-Class } \\
\text { Model } \\
\text { with a } \\
\text { Covariate } \\
\text { (Direct } \\
\text { effects) }\end{array}$ & $\begin{array}{l}\text { 3-Class } \\
\text { Model } \\
\text { with a } \\
\text { Covariate } \\
\text { (Indirect } \\
\text { effects) }\end{array}$ & $\begin{array}{l}\text { 3-Class } \\
\text { Model } \\
\text { without a } \\
\text { Covariate }\end{array}$ & $\begin{array}{l}\text { 4-Class } \\
\text { Model } \\
\text { with a } \\
\text { Covariate } \\
\text { (Direct } \\
\text { effects) }\end{array}$ & $\begin{array}{l}\text { 4-Class } \\
\text { Model* } \\
\text { with a } \\
\text { Covariate } \\
\text { (Indirect } \\
\text { effects) }\end{array}$ & $\begin{array}{l}\text { 4-Class } \\
\text { Model } \\
\text { without a } \\
\text { Covariate }\end{array}$ \\
\hline AIC & 29566.924 & 31099.474 & 34298.697 & 29589.630 & 32932.580 & 34274.414 & 29428.298 & 29832.116 & 34271.424 \\
\hline $\mathrm{BIC}$ & 29695.125 & 31189.215 & 34382.028 & 29769.223 & 33189.142 & 34402.615 & 29659.060 & 30024.418 & 34444.496 \\
\hline Entropy & 0.980 & 0.839 & 0.599 & 0.791 & 0.802 & 0.446 & 0.774 & 0.797 & 0.579 \\
\hline -2 Loglikelihood & 29526.924 & 31071.474 & 34272.698 & 29533.630 & 32852.580 & 34234.414 & 29356.298 & 29772.116 & 34217.424 \\
\hline \# of parameters & 20 & 14 & 13 & 28 & 40 & 20 & 36 & 30 & 27 \\
\hline
\end{tabular}


Appendix 2. Parameter Estimates and Fit Indices for the 2-, 3-, and 4-class Models: Unbalanced Data

\begin{tabular}{|c|c|c|c|c|c|c|c|c|c|}
\hline & $\begin{array}{l}\text { 2-Class } \\
\text { Model } \\
\text { with a } \\
\text { Covariate } \\
\text { (Direct } \\
\text { effects) }\end{array}$ & $\begin{array}{l}\text { 2-Class } \\
\text { Model } \\
\text { with a } \\
\text { Covariate } \\
\text { (Indirect } \\
\text { effects) }\end{array}$ & $\begin{array}{l}\text { 2-Class } \\
\text { Model } \\
\text { without a } \\
\text { Covariate }\end{array}$ & $\begin{array}{l}\text { 3-Class } \\
\text { Model } \\
\text { with a } \\
\text { Covariate } \\
\text { (Direct } \\
\text { effects) }\end{array}$ & $\begin{array}{l}\text { 3-Class } \\
\text { Model } \\
\text { with a } \\
\text { Covariate } \\
\text { (Indirect } \\
\text { effects) }\end{array}$ & $\begin{array}{l}\text { 3-Class } \\
\text { Model } \\
\text { without a } \\
\text { Covariate }\end{array}$ & $\begin{array}{l}\text { 4-Class } \\
\text { Model } \\
\text { with a } \\
\text { Covariate } \\
\text { (Direct } \\
\text { effects) }\end{array}$ & $\begin{array}{l}\text { 4-Class } \\
\text { Model* }^{*} \\
\text { with a } \\
\text { Covariate } \\
\text { (Indirect } \\
\text { effects) }\end{array}$ & $\begin{array}{l}\text { 4-Class } \\
\text { Model } \\
\text { without a } \\
\text { Covariate }\end{array}$ \\
\hline AIC & 861630.958 & 910666.404 & 1008455.485 & 858828.602 & 881946.275 & 1007346.986 & 857570.793 & 871309.659 & 1007247.696 \\
\hline $\mathrm{BIC}$ & 861826.928 & 910803.583 & 1008582.866 & 859102.962 & 882161.843 & 1007542.957 & 857923.541 & 871603.615 & 1007512.257 \\
\hline Entropy & 0.852 & 0.834 & 0.568 & 0.839 & 0.807 & 0.434 & 0.775 & 0.798 & 0.363 \\
\hline -2 Loglikelihood & 861590.958 & 910638.404 & 1008429.484 & 858772.602 & 881902.276 & 1007306.986 & 857498.794 & 871249.658 & 1007193.696 \\
\hline \# of parameters & 20 & 14 & 13 & 28 & 22 & 20 & 36 & 30 & 27 \\
\hline
\end{tabular}

"Note: 4-class model with a covariate and indirect effects is the model for LCA analyses in the present study.

Appendix 3. Latent Class Assignment for Balanced Data

\begin{tabular}{|c|c|c|c|c|c|c|c|c|c|c|c|}
\hline \multirow{2}{*}{$\begin{array}{c}\text { Disability } \\
\text { Status }\end{array}$} & \multirow[b]{2}{*}{ Accommodation } & \multicolumn{5}{|c|}{ ELLs } & \multicolumn{5}{|c|}{ Native English Speakers } \\
\hline & & $N$ & 1 & 2 & 3 & 4 & $N$ & 1 & 2 & 3 & 4 \\
\hline \multirow[t]{2}{*}{ LD } & Setting Only & 140 & $8.6 \%$ & $32.9 \%$ & $21.4 \%$ & $37.1 \%$ & 221 & $9.5 \%$ & $35.3 \%$ & $18.6 \%$ & $36.7 \%$ \\
\hline & None & 566 & $14.0 \%$ & $29.9 \%$ & $23.0 \%$ & $33.2 \%$ & 1052 & $13.2 \%$ & $33.6 \%$ & $20.6 \%$ & $32.6 \%$ \\
\hline \multirow{2}{*}{ Non-disabled } & Setting Only & 340 & $15.0 \%$ & $31.5 \%$ & $21.2 \%$ & $32.4 \%$ & 281 & $7.5 \%$ & $29.5 \%$ & $23.5 \%$ & $39.5 \%$ \\
\hline & None & 831 & $35.3 \%$ & $23.3 \%$ & $27.1 \%$ & $14.3 \%$ & 988 & $31.1 \%$ & $23.2 \%$ & $31.1 \%$ & $14.7 \%$ \\
\hline
\end{tabular}

Appendix 4. Latent Class Assignment for Unbalanced Data

\begin{tabular}{|c|c|c|c|c|c|c|c|c|c|c|c|}
\hline \multirow{2}{*}{$\begin{array}{c}\text { Disability } \\
\text { Status }\end{array}$} & \multirow[b]{2}{*}{ Accommodation } & \multicolumn{5}{|c|}{ ELLs } & \multicolumn{5}{|c|}{ Native English Speakers } \\
\hline & & $N$ & 1 & 2 & 3 & 4 & $N$ & 1 & 2 & 3 & 4 \\
\hline \multirow[t]{2}{*}{ LD } & Setting Only & 144 & $2.8 \%$ & $33.3 \%$ & $44.4 \%$ & $19.4 \%$ & 226 & $5.3 \%$ & $38.9 \%$ & $41.2 \%$ & $14.6 \%$ \\
\hline & None & 573 & $4.0 \%$ & $34.6 \%$ & $38.9 \%$ & $22.5 \%$ & 1075 & $4.4 \%$ & $33.4 \%$ & $39.6 \%$ & $22.6 \%$ \\
\hline \multirow{2}{*}{ Non-disabled } & Setting Only & 346 & $7.8 \%$ & $29.2 \%$ & $40.5 \%$ & $22.5 \%$ & 287 & $2.8 \%$ & $36.9 \%$ & $45.3 \%$ & $15.0 \%$ \\
\hline & None & 49658 & $17.2 \%$ & $28.8 \%$ & $17.1 \%$ & $36.9 \%$ & 61591 & $12.4 \%$ & $32.5 \%$ & $19.0 \%$ & $36.1 \%$ \\
\hline
\end{tabular}


Appendix 5. Overall Percentage Correct of Latent Classes in Balanced and Unbalanced Data

\begin{tabular}{rrrrrr} 
Balanced & Class 1 & Class 2 & Class 3 & Class 4 & Overall \\
\hline Item 1 & $71.20 \%$ & $49.50 \%$ & $72.80 \%$ & $29.80 \%$ & $54.60 \%$ \\
Item 2 & $59.40 \%$ & $34.30 \%$ & $24.90 \%$ & $12.70 \%$ & $31.60 \%$ \\
Item 3 & $96.40 \%$ & $39.70 \%$ & $64.90 \%$ & $12.20 \%$ & $50.60 \%$ \\
Item 4 & $100.00 \%$ & $50.00 \%$ & $66.50 \%$ & $10.00 \%$ & $54.10 \%$ \\
Item 5 & $89.80 \%$ & $44.60 \%$ & $73.20 \%$ & $15.20 \%$ & $53.40 \%$ \\
Item 6 & $87.10 \%$ & $18.50 \%$ & $38.90 \%$ & $5.40 \%$ & $34.40 \%$ \\
\hline
\end{tabular}

\begin{tabular}{crrrrr} 
Unbalanced & Class 1 & Class 2 & Class 3 & Class 4 & Overall \\
\hline Item 1 & $99.90 \%$ & $49.55 \%$ & $48.00 \%$ & $57.50 \%$ & $55.70 \%$ \\
Item 2 & $99.95 \%$ & $23.60 \%$ & $13.85 \%$ & $36.80 \%$ & $31.70 \%$ \\
Item 3 & $90.25 \%$ & $60.30 \%$ & $11.60 \%$ & $71.55 \%$ & $52.60 \%$ \\
Item 4 & $86.90 \%$ & $61.20 \%$ & $13.60 \%$ & $82.15 \%$ & $55.75 \%$ \\
Item 5 & $84.65 \%$ & $54.95 \%$ & $23.85 \%$ & $75.50 \%$ & $54.85 \%$ \\
Item 6 & $66.67 \%$ & $8.33 \%$ & $4.47 \%$ & $46.83 \%$ & $24.10 \%$ \\
\hline
\end{tabular}
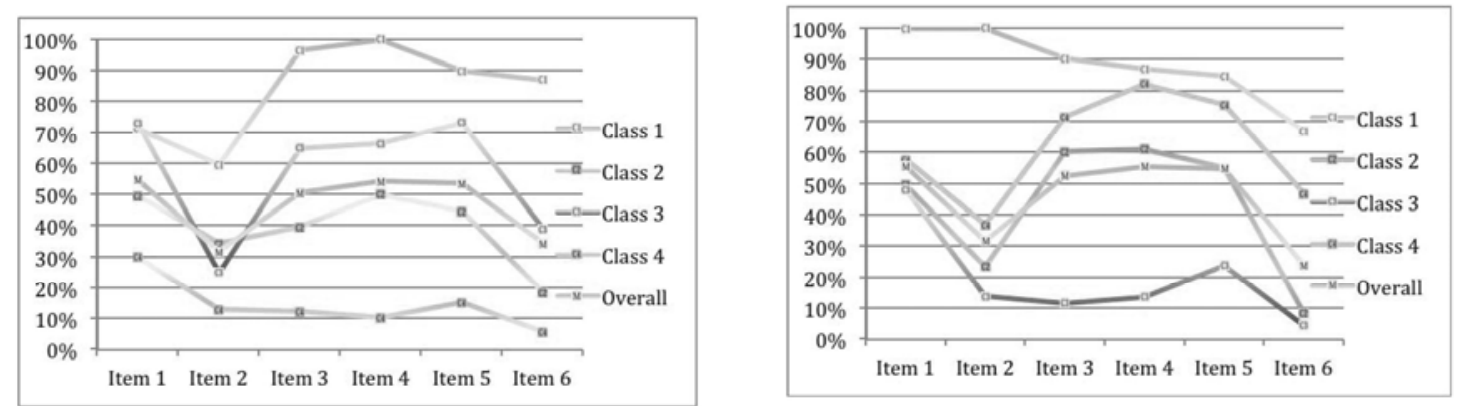

Figure 1. Overall percentage correct of latent classes on multiple-choice number sense in the balanced and unbalanced data 
Appendix 6. Percentage Correct and Missing Response Rate in Balanced Data

\begin{tabular}{|c|c|c|c|c|c|c|c|c|c|c|c|c|c|}
\hline \multirow[b]{2}{*}{ Item } & \multirow[b]{2}{*}{ Disability } & \multirow[b]{2}{*}{ Group } & \multicolumn{6}{|c|}{ ELL students (\%) } & \multicolumn{5}{|c|}{ Native English Speakers (\%) } \\
\hline & & & & Class 1 & Class 2 & Class 3 & Class 4 & Overall & Class 1 & Class 2 & Class 3 & Class 4 & Overall \\
\hline \multirow[t]{8}{*}{ Item 1} & LD & Setting & Correct & 58.30 & 45.70 & 76.70 & 42.30 & 52.10 & 66.70 & 47.40 & 73.20 & 33.30 & 48.90 \\
\hline & & & Missing & 0.00 & 0.00 & 0.00 & 0.00 & 0.00 & 0.00 & 0.00 & 0.00 & 0.00 & 0.00 \\
\hline & & None & Correct & 58.20 & 50.30 & 73.80 & 26.10 & 48.80 & 66.90 & 50.70 & 61.30 & 28.90 & 47.90 \\
\hline & & & Missing & 0.00 & 0.00 & 0.00 & 0.00 & 0.00 & 0.00 & 0.00 & 0.00 & 0.00 & 0.00 \\
\hline & & Setting & Correct & 62.70 & 43.00 & 73.60 & 25.50 & 46.80 & 57.10 & 47.00 & 74.20 & 29.70 & 47.30 \\
\hline & Non-disabled & & Missing & 0.00 & 0.00 & 0.00 & 0.00 & 0.00 & 0.00 & 0.00 & 0.00 & 0.90 & 0.40 \\
\hline & & None & Correct & 76.10 & 52.10 & 81.80 & 26.90 & 65.00 & 100.00 & 100.00 & 100.00 & 100.00 & 100.00 \\
\hline & & & Missing & 0.00 & 0.00 & 0.00 & 0.00 & 0.00 & 0.00 & 0.00 & 0.00 & 0.00 & 0.00 \\
\hline \multirow[t]{8}{*}{ Item 2} & LD & Setting & Correct & 50.00 & 30.40 & 20.00 & 9.60 & 22.10 & 61.90 & 28.20 & 19.50 & 16.00 & 25.30 \\
\hline & & & Missing & 0.00 & 2.20 & 0.00 & 0.00 & 0.70 & 0.00 & 0.00 & 0.00 & 0.00 & 0.00 \\
\hline & & None & Correct & 51.90 & 39.10 & 30.80 & 12.20 & 30.00 & 52.50 & 32.00 & 22.10 & 12.20 & 26.20 \\
\hline & & & Missing & 0 & 0.60 & 0.00 & 0.50 & 0.40 & 0.00 & 0.30 & 0.50 & 0.60 & 0.40 \\
\hline & Non-disabled & Setting & Correct & 74.50 & 30.80 & 38.90 & 13.60 & 33.50 & 61.90 & 31.30 & 19.70 & 9.00 & 22.10 \\
\hline & & & Missing & 0.00 & 0.00 & 0.00 & 0.00 & 0.00 & 0.00 & 0.00 & 0.00 & 0.00 & 0.00 \\
\hline & & None & Correct & 60.80 & 36.10 & 28.90 & 17.60 & 40.20 & 60.60 & 38.40 & 20.50 & 11.70 & 35.80 \\
\hline & & & Missing & 0.00 & 0.00 & 0.40 & 0.00 & 0.10 & 0.00 & 0.00 & 0.30 & 0.00 & 0.10 \\
\hline \multirow[t]{8}{*}{ Item 3} & LD & Setting & Correct & 83.30 & 37.00 & 56.70 & 15.40 & 37.10 & 85.70 & 35.90 & 63.40 & 13.60 & 37.60 \\
\hline & & & Missing & 0.00 & 0.00 & 0.00 & 0.00 & 0.00 & 0.00 & 0.00 & 0.00 & 2.50 & 0.90 \\
\hline & & None & Correct & 100.00 & 43.20 & 61.50 & 11.20 & 44.70 & 96.40 & 35.70 & 63.10 & 9.90 & 41.00 \\
\hline & & & Missing & 0.00 & 0.00 & 0.00 & 1.10 & 0.40 & 0.00 & 0.30 & 0.50 & 0.30 & 0.30 \\
\hline & Non-disabled & Setting & Correct & 92.20 & 37.40 & 62.50 & 10.90 & 42.40 & 100.00 & 33.70 & 54.50 & 9.90 & 34.20 \\
\hline & & & Missing & 0.00 & 0.00 & 0.00 & 0.90 & 0.30 & 0.00 & 0.00 & 0.00 & 0.00 & 0.00 \\
\hline & & None & Correct & 98.00 & 44.80 & 68.40 & 17.60 & 66.10 & 95.80 & 44.10 & 68.70 & 15.20 & 63.60 \\
\hline & & & Missing & 0.00 & 0.50 & 0.00 & 1.70 & 0.40 & 0.00 & 0.00 & 0.00 & 0.00 & 0.00 \\
\hline \multirow[t]{8}{*}{ Item 4} & LD & Setting & Correct & 100.00 & 45.70 & 63.30 & 17.30 & 43.60 & 100.00 & 53.80 & 63.40 & 8.60 & 43.40 \\
\hline & & & Missing & 0.00 & 0.00 & 3.30 & 1.90 & 1.40 & 0.00 & 0.00 & 0.00 & 3.70 & 1.40 \\
\hline & & None & Correct & 100.00 & 46.70 & 67.70 & 9.00 & 46.50 & 100.00 & 51.00 & 73.30 & 8.70 & 48.30 \\
\hline & & & Missing & 0.00 & 0.00 & 0.00 & 1.10 & 0.40 & 0.00 & 0.00 & 0.50 & 0.90 & 0.40 \\
\hline & Non-disabled & Setting & Correct & 100.00 & 46.70 & 58.30 & 10.90 & 45.60 & 100.00 & 47.00 & 69.70 & 9.90 & 41.60 \\
\hline & & & Missing & 0.00 & 0.00 & 0.00 & 0.90 & 0.30 & 0.00 & 0.00 & 0.00 & 0.90 & 0.40 \\
\hline & & None & Correct & 100.00 & 50.00 & 61.30 & 10.90 & 65.10 & 100.00 & 52.80 & 67.10 & 11.00 & 65.80 \\
\hline & & & Missing & 0.00 & 0.50 & 0.00 & 2.50 & 0.50 & 0.00 & 0.00 & 0.00 & 0.70 & 0.10 \\
\hline \multirow[t]{8}{*}{ Item 5} & LD & Setting & Correct & 91.70 & 50.00 & 76.70 & 9.60 & 44.30 & 85.70 & 35.90 & 75.60 & 16.00 & 40.70 \\
\hline & & & Missing & 0.00 & 0.00 & 0.00 & 0.00 & 0.00 & 0.00 & 0.00 & 0.00 & 3.70 & 1.40 \\
\hline & & None & Correct & 86.10 & 37.30 & 70.80 & 14.40 & 44.20 & 84.90 & 43.60 & 65.00 & 15.50 & 44.30 \\
\hline & & & Missing & 0.00 & 0.00 & 0.00 & 0.50 & 0.20 & 0.00 & 0.30 & 0.00 & 0.30 & 0.20 \\
\hline & Non-disabled & Setting & Correct & 86.30 & 43.00 & 77.80 & 12.70 & 47.10 & 76.20 & 43.40 & 69.70 & 18.00 & 42.00 \\
\hline & & & Missing & 0.00 & 0.00 & 0.00 & 0.90 & 0.30 & 0.00 & 1.20 & 0.00 & 0.00 & 0.40 \\
\hline & & None & Correct & 94.50 & 50.50 & 77.30 & 19.30 & 68.80 & 90.20 & 49.30 & 75.90 & 13.80 & 65.10 \\
\hline & & & Missing & 0.00 & 0.50 & 0.40 & 1.70 & 0.50 & 0.00 & 0.00 & 0.00 & 0.00 & 0.00 \\
\hline \multirow[t]{8}{*}{ Item 6} & LD & Setting & Correct & 100.00 & 4.30 & 36.70 & 3.80 & 19.30 & 90.50 & 19.20 & 43.90 & 3.70 & 24.90 \\
\hline & & & Missing & 0.00 & 0.00 & 0.00 & 0.00 & 0.00 & 0.00 & 0.00 & 0.00 & 2.50 & 0.90 \\
\hline & & None & Correct & 82.30 & 20.10 & 27.70 & 3.70 & 25.10 & 82.70 & 17.30 & 35.90 & 6.40 & 26.20 \\
\hline & & & Missing & 0.00 & 0.00 & 0.00 & 2.10 & 0.70 & 0.00 & 0.00 & 0.50 & 2.30 & 0.90 \\
\hline & Non-disabled & Setting & Correct & 88.20 & 16.80 & 34.70 & 6.40 & 27.90 & 81.00 & 10.80 & 31.80 & 4.50 & 18.50 \\
\hline & & & Missing & 0.00 & 0.00 & 0.00 & 1.80 & 0.60 & 0.00 & 0.00 & 0.00 & 0.90 & 0.40 \\
\hline & & None & Correct & 90.10 & 26.30 & 44.40 & 8.40 & 51.10 & 87.00 & 18.80 & 43.60 & 4.10 & 45.50 \\
\hline & & & Missing & 0.00 & 0.50 & 0.00 & 3.40 & 0.60 & 0.00 & 0.00 & 0.00 & 0.70 & 0.10 \\
\hline
\end{tabular}


Appendix 7. Percentage Correct and Missing Response Rate in Unbalanced Data

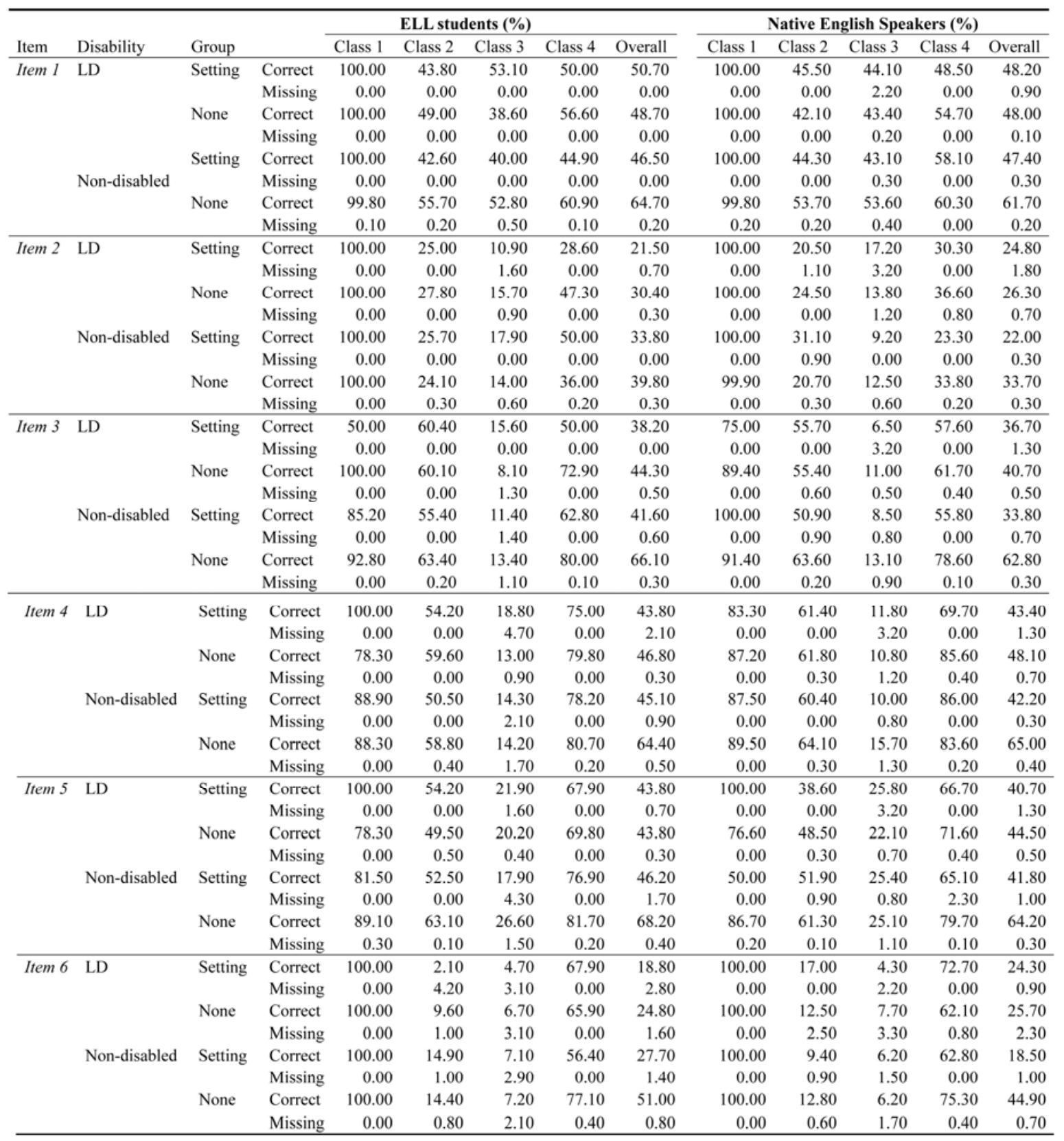

\section{Copyright Disclaimer}

Copyright reserved by the author(s).

This article is an open-access article distributed under the terms and conditions of the Creative Commons Attribution license (http://creativecommons.org/licenses/by/3.0/). 